\title{
ANTI-TUMOR ACTIVITY OF BACTERIAL LECTIN AND 5-METHYLURACIL ADDUCT
}

\author{
Elena Welchinska ${ }^{1}$
}

\begin{abstract}
The synthesis was performed using 5-methyluracil mono-and bis-derivatives with the halogencontaining pharmacophore groups in the composition of molecules; their physiochemical and biological properties were studied. These reactions are a typical example of substitution reactions on heteroatom $\mathrm{N}^{(1)}$ of uracil molecule using as the second component the reaction of halothane-the known inhaled anesthetic. The reactions were carried out in a solvent system: benzene-dimethyl formamide and diethyl ether, under conditions of phase transfer catalysis DB-18-crown-6-complex (alkaline medium), by heating from 2 to 11 hours, followed by purification, and drying of the resulting products.

The structure of the synthesized compounds was confirmed by elemental analysis, IR and ${ }^{1} \mathrm{HNMR}$ spectra. The purity was controlled by the methods of thin-layer and gas-liquid chromatography. Chromatography, IR and ${ }^{1}$ HNMR spectra of the final products were identified in comparison with the chromatograms, IR and ${ }^{1}$ HNMR spectra of the initial compounds. Variation of the reaction conditions and changes in methods of synthesis enabled to receive the synthesized compounds of high purity and to increase their practical output up to 43-80\%. Molecular complex of Bacterial lectin and 5-methyluracil bis-derivative was obtained.

The toxicity and anti-tumor activity of some of the synthesized compounds were investigated. We have found that the new molecular complex of Bacterial lectin and 5-methyluracil bis-derivative has high antitumor activity in Limphosarcoma Plissa-62.8\% (activity criterion $\geq 50 \%$ ), which allows us to consider the synthesized compound as a physiologically active compound with the prospect for further study as a potential vehicle for anti-tumoral treatment in patients.
\end{abstract}

UDC Classification: 547.431.4 - 547.854.4; 547.96, DOI: http://dx.doi.org/10.12955/cbup.v2.476

Keywords: 5-methyluracile, halothane, anti-tumor, synthesis, toxicity

\section{Introduction}

Treating patients with malignant neoplasms and finding effective low toxic anticancer medicines are among the most important tasks in modern medicine, and the medicinal and pharmaceutical chemistry. Knowledge of the features of a cancer cell and its metabolism enables us to predict the direction of chemical and biological research, to conduct a targeted synthesis of potential drugs, and to assess their applicability in oncological practice as anti-tumor agents. One of the most successful directions of search for new anti-tumor agents is the study of antimetabolites of pyrimidine and purine exchange, which acts as preformed compounds in several biosynthetic processes (DNA and RNA-specific proteins) inhibiting tumor growth (Abou-Gharbia \& Patel-Usha, 1988; Alonso, Shaw, Wright, 1984; Perevodchikova, 2005; Brody \& Sweet, 1963; Brown \& Sipes, 1977).

Among modern anti-cancer agents, a significant place is given to substances belonging to the nitrogencontaining heterocyclic systems, which are the bio-isosteric analogs of a number of natural compounds (Adjei, 1999; Barlow, 1959; Anderson \& Lokich, 1992; Anttila, Sotaniemi, \& Kairaluoma, 1983; Benz, Tills, \& Tattelman, 1982; Longley \& Harkin, 2004; Noordhuis \& Holwerda, 2004; Au, Wu, \& Friedman, 1979; Baba, Kohnoe, \& Endo, 2000; Yagupolskiy, 1988). However, this direction is not sufficiently developed at present and requires a more systematic approach to addressing issues of grounded selection of promising compounds, and exploring opportunities of creation on their basis of the medicinal forms, pharmaceutical research design, and analysis of rational therapy.

In this connection, the work that is dedicated to solving the problem of creating anti-tumor agents based on derivatives of purine and pyrimidine series presents considerable scientific interest; it is of key relevance, and contains a scientific novelty and practical value. A new method was developed and the known preparative methods of synthesis of mono- and bis-uracil derivatives with the pharmacophore groups were modified: $-(\mathrm{HO}) \mathrm{C}=\mathrm{CBrCl}, \quad-\mathrm{CF}_{2}-\mathrm{CHBrCl}, \quad=\mathrm{C}=\mathrm{CBrCl}$, -

\footnotetext{
${ }^{1}$ Elena Welchinska, Bogomolets National Medical University, Kiev, Ukraine, elena_wwu@ukr.net
} 
$\mathrm{C}\left(\mathrm{CF}_{3}\right)=\mathrm{C}\left(\mathrm{COOC}_{2} \mathrm{H}_{5}\right)_{2}$; their chemical structure and composition were identified, and their physicchemical properties were studied. Molecular complex of Bacterial lectin Bacillus polymyxa $102 \mathrm{KGU}$ and 5-methyluracil bis-derivative was obtained. For the first time in a single experimental setting, the anti-tumor activity of selected compounds was studied in experiments in vivo and in vitro in cancer Limphosarcoma Plissa. As a result, the agent with a significant anti-tumor effect was discovered. For the first time, the interaction of a series of substituted uracil with halothane was investigated; the conditions of the reaction were defined; the methods were developed; and the composition of the reaction products was studied. The studies revealed that the initial heterocycle (5-methyluracil) reacts with the intermediate product of halothane (I) conversion in an alkaline medium (II), under conditions of phase transfer catalysis DB-18-crown-6 in a solvent system (dimethyl formamide/benzene/diethyl ether) or in another variant: DMSO in the presence of anhydrous potassium carbonate with the formation of mono-and bis-derivatives of 5-methyluracil (III-V). This reaction enabled the development of a new strategy for the synthesis of selectively poly-functionalized molecules, the chemical structure of which is available for incorporation of new pharmacophore fragments into the molecule (Welchinskaya, 1997). To expand the list of convenient and chemically available reagents, for introduction of fluorinated substituents into the heterocyclic molecules, the aforementioned synthesis method was modified, and, as the result, a new compound was synthesized-1,1-dicarbethoxy-2-trifluoromethyl-2-chloroethylene (VI). Synthesis was carried out by acylation of diethyl malonate by the anhydride of trifluoroacetate acid (or by the trifluoroacetate acid) in the presence of sodium methylate, followed by treating the product of the first reaction step with phosphorus pentachloride in dichloroethane. Through a nucleophilic substitution reaction, between 5-methyluracil and compound VI with a chlorine atom in the molecule, activated by two dicarbethoxy-groups in the non-aqueous solvents (DMF-diethyl ether) in the presence of anhydrous triethylamine, a new pyrimidine (VII) was synthesized. The aforementioned chemical reactions are shown in Figure 1.

New compounds III-V, VII, molecular complex of Bacillus polymyxa $102 \mathrm{KGU}$, and 5methyluracil bis-derivative were tested on the cancer Limphosarcoma Plissa.

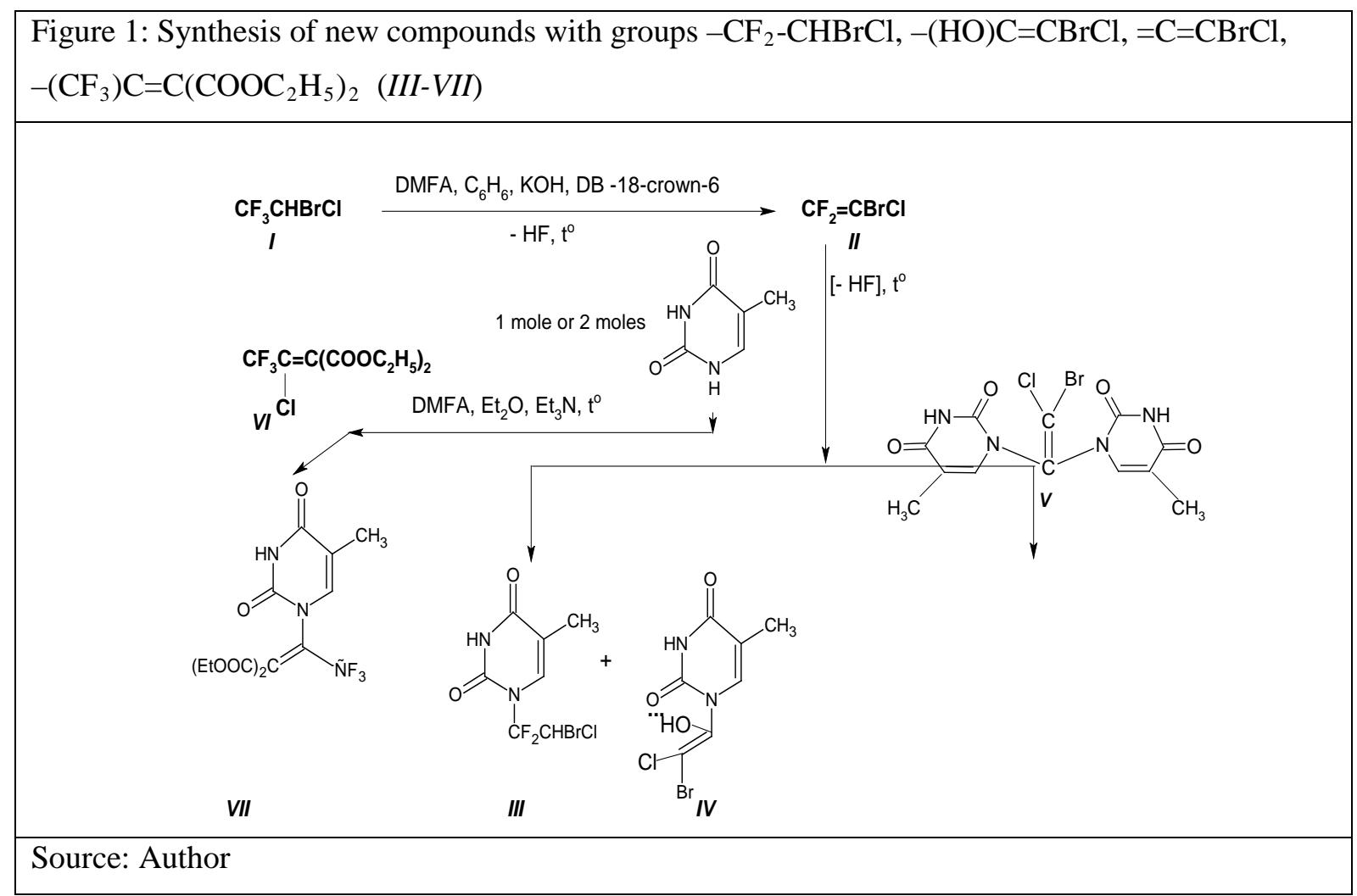




\section{Methods}

The majority of the absolute organic solvents (benzene, dimethyl formamide (DMFA), hexane, and ethyl ester) employed in the present studies were distilled before their use. Organic solvents were dried over anhydrous magnesium sulfate or metallic sodium. Gas-liquid chromatography was carried out by Perkin Elmer chromatograph with UV-detector ("Perkin,” Germany). IR spectra were recorded in a UR-20 spectrometer ("Charles Ceise Hena," Germany). The ${ }^{1} \mathrm{HNMR}$ spectra were recorded in DMSO-d6 on a $200 \mathrm{MHz}$ BrakerWP-200 ("Braker," Switzerland) or Varian T-60 spectrometer ("Varian,” USA). New compounds with significant anti-tumor activity were selected and investigated (Prozorovskiy, 1978; Sophina, 1979). Lymphosarcoma Plissa was obtained from imbredical rats, which received 3,3-dichlorobenzidine (Blohin, 1984). The white imbredical mice and experimental model of tumor growth - cancer Limphosarcoma Plissa, were used following published procedures in Prozorovskiy (1978). The experimental tumors used for our investigation were obtained from Strain Bank of Oncological Centre of Russian Academy of Medical Sciences. The experimental tumors were used for passage on experimental animals, and program freezing. Afterward, these would be preserved in Strain Bank of Institute of Pharmacology and Toxicology of National Academy of Medical Sciences of Ukraine. The efficiency parameter (\% of tumor growth relaxation [volume and mass]) is $\geq 50 \%$ in case of cancer Limphosarcoma Plissa. The results were assessed by standard methods of statistical analysis (Prozorovskiy, 1978; Sophina, 1979). Investigation of critical toxicity of new compounds was carried out at Institute of Pharmacology and Toxicology of National Academy of Medical Sciences of Ukraine. The method of introduction was under the skin. The lectin preparations were obtained by treatment of saprophytic strain Bacillus Liquid culture from Ukrainian Collection of Microorganisms of Institute of Microbiology and Virology (IMV): B. polymyxa 102 KGU (lectin 102) clarified by treatment with ammonium sulfate (70\% concentration of a saturated solution). The precipitate containing the lectin was dissolved in water, dialyzed against water, and freeze-dried as described by Kovalenko (1990). Molecular complex of bis-adduct and bacterial lectin was obtained by mixing two components at physiological solution, 1:1.

\section{Chemistry and anti-tumor activity of derivatives obtained from the base of 5- methyluracil}

\section{Chemistry}

The following is a procedure for the preparation of $\mathrm{N}^{(1)}-\left(1^{\prime}, 1^{\prime}\right.$-difluoro-2'-bromo-2'-chloroethyl)-5methyluracil (III) and $\mathrm{N}^{(1)}$-(2'-bromo-1'-hydroxy-2'-chloroethenyl)-5-methyluracil (IV).

Solution I is a mixture of potassium hydroxide $(0.44 \mathrm{~g}, 0.0079 \mathrm{~mol})$ and dibenzo-18-crown-6-complex ( $0.044 \mathrm{~g}, 0.0079 \mathrm{~mol})$ in $20 \mathrm{ml}$ of dry benzene is heated under reflux at $60-80^{\circ} \mathrm{C}$ for 15 minutes. The cooled solution is mixed with halothane $(1.57 \mathrm{~g}, 0.84 \mathrm{ml}, 0.0079 \mathrm{~mol})$ in $20 \mathrm{ml}$ of dry ethyl ester. Solution I is heated under reflux at $60-80^{\circ} \mathrm{C}$ for 15 minutes. Then, the cooled Solution I is mixed with solution II (5-methyluracil [1.0 g, $0.0079 \mathrm{~mol}$ ] in $40 \mathrm{ml}$ of dry dimethylformamide) and then heated under reflux at $60-80^{\circ} \mathrm{C}$ for 5 hours. The heated solution is filtered, and the precipitate is rinsed with $30 \mathrm{ml}$ of ethyl ester-hexane mixture (1:1), then dried under vacuum.

Adduct III is a cream-colored solid (32\%) having a melting point of $277-280^{\circ} \mathrm{C}$. Found (\%): N 9.20. $\mathrm{C}_{7} \mathrm{H}_{6} \mathrm{BrClF}_{2} \mathrm{~N}_{2} \mathrm{O}_{2}$. Calculated (\%): N 9.23. $\gamma_{\max }(\mathrm{KBr})\left(\mathrm{cm}^{-1}\right)$ : 550-690, 1710, 1750, 2820-3000; $\sigma \mathrm{H}$ $1.714\left(3 \mathrm{H}, \mathrm{CH}_{3}\right), 5.765-5.780\left(1 \mathrm{H}, \mathrm{J}_{\mathrm{H}, \mathrm{F}}^{3} 5.4 \mathrm{~Hz}, \mathrm{~J}_{\mathrm{H}, \mathrm{Cl}(\mathrm{Br})}^{2} 0.8 \mathrm{~Hz}, \mathrm{CF}_{2} \mathrm{CHBrCI}\right), 7.219\left(\mathrm{H}, \mathrm{C}_{(6)} \mathrm{H}\right)$, $10.580\left(1 \mathrm{H}, \mathrm{N}_{(3)} \mathrm{H}\right)$. Cooled filtrate is left overnight. The remainder (Adduct $I V$ ) is an oil, which has crystallized from the mix of ethyl ester-hexane (1:1). Solid is obtained by drying with air (25\%). Melting point: $272-276^{\circ} \mathrm{C}$. Found (\%): N 9.9. $\mathrm{C}_{7} \mathrm{H}_{6} \mathrm{BrClN}_{2} \mathrm{O}_{3}$. Calculated (\%): $\mathrm{N}$ 10.0. $\gamma_{\max }(\mathrm{KBr})$ 
$\left(\mathrm{cm}^{-1}\right)$ : 550-690, 1710, 1750, 2820-3000, 3200-3400; $\sigma \mathrm{H} 1.733\left(3 \mathrm{H}, \mathrm{CH}_{3}\right), 7.254\left(1 \mathrm{H}, \mathrm{C}_{(6)} \mathrm{H}\right), 10.62$ $\left(1 \mathrm{H}, \mathrm{N}_{(3)} \mathrm{H}\right), 11.03(1 \mathrm{H}, \mathrm{OH})$.

$N^{(1)}, N^{(1)}$-(2"-bromo-2"-chloroethenyl)-bis-(5-methyluracil) or Adduct $V$ is prepared according to the general procedure. Adduct $\mathrm{V}$ is a yellow-colored solid (43\%). Melting point: $286-289^{\circ} \mathrm{C}$. Found (\%): $\mathrm{N}$ 14.32. $\mathrm{C}_{12} \mathrm{H}_{10} \mathrm{BrClN}_{4} \mathrm{O}_{4}$. Calculated (\%): N 14.38. $\gamma_{\max }(\mathrm{KBr})\left(\mathrm{cm}^{-1}\right): 515,550,690,850,960-$ 970,1710, 1750, 2800-3000; $\sigma \mathrm{H} 1.712\left(6 \mathrm{H}, \mathrm{J}_{\mathrm{H}, \mathrm{H}}^{2} 5 \mathrm{~Hz}, 2 \mathrm{CH}_{3}\right), 7.229\left(2 \mathrm{H}, \mathrm{J}_{\mathrm{H}, \mathrm{H}} 5 \mathrm{~Hz}, 2 \mathrm{C}_{(6)} \mathrm{H}\right), 10.7$ $\left(2 \mathrm{H}, 2 \mathrm{~N}_{(3)} \mathrm{H}\right)$.

1,1-dicarbethoxy-2-trifluoromethyl-2-chloroethylene or Adduct VI is a mixture of metallic sodium (6.13 g, $0.268 \mathrm{~mol})$ in $250 \mathrm{ml}$ of methanol anhydrous. Diethyl ester of malonic acid $(43.0 \mathrm{~g}, 40 \mathrm{ml}$, $0.268 \mathrm{~mol})$ and trifluoroacetic acid ( $62.0 \mathrm{~g}, 40 \mathrm{ml}, 0.543 \mathrm{~mol})$ are heated under reflux at $60-80^{\circ} \mathrm{C}$ for 6 hours. Glass-shaped mass with white color ethyl ester is added to the product. The precipitate is a white-colored solid (product A). A mixture of product A $(8.0 \mathrm{~g}, 0.0287 \mathrm{~mol})$ in $55 \mathrm{ml}$ of dry dichloroethane and phosphorus pent chloride $(6.0 \mathrm{~g}, 0.0287 \mathrm{~mol})$ is heated to boiling for 5 hours. The precipitate is filtered and rinsed with dichloroethane. Adduct VI is an oil (80\%). Boiling point: 56$59^{\circ} \mathrm{C}(25 \mathrm{mmHg}), \mathrm{n}^{25}{ }_{\mathrm{D}}$ 1.3010. Found (\%): C 39.36; $\mathrm{H}$ 3.67; F 20.75. $\mathrm{C}_{9} \mathrm{H}_{10} \mathrm{ClF}_{3} \mathrm{O}_{4}$. Calculated (\%): C 39.37; H 3.64; F 20.76. $\gamma_{\max }(\mathrm{KBr})\left(\mathrm{cm}^{-1}\right): 400,415$, 470, 560, 730, 905, 995, 1180, 1230, $1295,1315,1600,1735,2800-3000 ; \sigma \mathrm{H} 1.19\left(6 \mathrm{H}, \mathrm{J}_{\mathrm{H}, \mathrm{H}}^{3} 7.2 \mathrm{~Hz}, 2 \mathrm{CH}_{3}\right), 4.10\left(4 \mathrm{H}_{,} \mathrm{J}_{\mathrm{H}, \mathrm{H}}^{3} 7.2 \mathrm{~Hz}\right.$, $\left.2 \mathrm{OCH}_{2}\right)$.

$N^{(1)}$-(1-trifluoromethyl-2,2-dicarbethoxyethenyl)-2,4-dioxo-3,4-dihydro-2H-pyrimidine or Adduct VII is a mixture of 5-methyluracil $(0.87 \mathrm{~g}, 0.0069 \mathrm{~mol})$ in $30 \mathrm{ml}$ of dry dimethylformamide. Anhydrous triethylamine $(0.71 \mathrm{~g}, 0.94 \mathrm{ml}, 0.0069 \mathrm{~mol})$ and Adduct VI $(1.92 \mathrm{~g}, 0.0069 \mathrm{~mol})$ in $10 \mathrm{ml}$ of dry diethyl ester are heated at $60-70^{\circ} \mathrm{C}$ for 2 hours, filtered, and $\left.\mathrm{N}_{(} \mathrm{C}_{2} \mathrm{H}_{5}\right)_{3} \times \mathrm{HC} 1$ is withdrawn. The yellow-colored oil is rinsed with $10 \mathrm{ml}$ of hexane and $10 \mathrm{ml}$ of acetone. Adduct VII is a cream-colored solid (35\%). Melting point: 272-275 ${ }^{\circ}$ C. Found (\%): N 7.59. $\mathrm{C}_{14} \mathrm{H}_{15} \mathrm{~F}_{3} \mathrm{~N}_{2} \mathrm{O}_{6}$. Calculated (\%): $\mathrm{N}$ 7.63. $\gamma_{\max }(\mathrm{KBr})\left(\mathrm{cm}^{-1}\right): 400,415,470,560,600-800,905,995,1180,1230,1295,1050-1150,1300-$ 1600, 1315, 1600, 1710, 1715, 1735, 3010-3080; $\sigma \mathrm{H} 1.18\left(6 \mathrm{H}_{,} \mathrm{J}_{\mathrm{H}, \mathrm{H}}^{3} 7.0 \mathrm{~Hz}, 2 \mathrm{CH}_{3}\right), 1.76\left(3 \mathrm{H}, \mathrm{CH}_{3}\right.$ $\left.\left(\mathrm{C}_{(5)} \mathrm{H}\right)\right), 3.737-4.315\left(4 \mathrm{H}, \mathrm{J}_{\mathrm{H}, \mathrm{H}}^{3} 7.0 \mathrm{~Hz}, 2 \mathrm{OCH}_{2}\right), 7.78\left(1 \mathrm{H}, \mathrm{J}_{\mathrm{H}, \mathrm{H}}^{2} 10.0 \mathrm{~Hz}, \mathrm{C}_{(6)} \mathrm{H}\right), 8.57\left(1 \mathrm{H}, \mathrm{N}_{(3)} \mathrm{H}\right)$.

\section{Biology}

All isolated males of imbredical mice were provided with standard food ration in all groups with the same control. The quantity of animals in each group was six. Minimum weight of mice body was $17.0 \pm 2.0 \mathrm{~g}$. The age of the mice was $2-3$ months. Percentage of primary recovery and destruction is " 0. " Method of killing was decapitation and ethyl ester overdose. The method of the experimental tumors removal was surgery. The efficiency parameter (\% growth relaxation of tumor [volume and weight]) was calculated by the following formula (Sophina, 1979):

(average data of tumor growth in control) - (average data of tumor growth in experimental group)

(average data of tumor growth in control) $\times 100 \%$

There were six introductions of the physiological solutions of adducts III-V, and VII every day. The dosage of the preparations corresponded to $1 / 4-1 / 6$ of the $L_{50}$. Results were calculated within 24 hours after the treatment had ended. The main control data are: average weight of the tumor in the control animals (g), average weight of the tumor in experimental animals (g), \% of growth relaxation of the tumor, index of effectiveness, and spleen ratio. The considerable criterion is $\geq 50.0 \%$ of growth relaxation of the tumor. Preparation of standard was 5-flurouracil (5-FU). The express-method of definition of $\mathrm{LD}_{50}$ was used (Prozorovskiy, 1978). Results were calculated via alternative formula 2 weeks after the introductions. Statistical analysis was carried out according to Perevodchikova (2005). 
The dosages of substances were from 600 to $250 \mathrm{mg} / \mathrm{kg}$. Tonic convulsions duration was $1-2$ hours; vomiting by experimental animals was observed.

\section{Results and Discussions}

The chemical composition and structure of new mono- and bis-adducts of 5-methyluracil, molecular complex of lectin 102 and bis-adduct 5-methyluracil, toxicity and anti-tumor activity of the new compounds have been studied. It was shown that mono- and bis-adducts of 5-methyluracile III- $V$, and VII were less toxic (1.2-1.5 times) than control substance 5-FU ( $\mathrm{LD}_{50}$ is $375 \mathrm{mg} / \mathrm{kg}$ ), but molecular complex of Bacillus polymyxa $102 \mathrm{KGU}$ and 5-methyluracil bis-derivative $V$ was insignificantly more toxic than $5-F U$. $\mathrm{LD}_{50}$ ranges from $568 \mathrm{mg} / \mathrm{kg}$ up to $335 \mathrm{mg} / \mathrm{kg}$. Toxicity data of these products are shown in Table 1.

Table 1: Parameters of adducts toxicity (III-V, VII, and molecular complex), compared with 5-FU

\begin{tabular}{|c|c|c|}
\hline № & Adduct & $\mathrm{LD}_{50}, \mathrm{mg} / \mathrm{kg}$ \\
\hline 1. & $\mathrm{~N}^{(1)}$-(1',1'-difluoro-2'-bromo-2'-chloroethyl)-5-methyluracil (III) & 485.00 \\
\hline 2. & $\mathrm{~N}^{(1)}$-(2'-bromo-1'-hydroxy-2'-chloroethenyl)-5-methyluracil (IV) & 479.00 \\
\hline 3. & $\mathrm{~N}^{(1)}, \mathrm{N}^{(1)}-\left(2^{2}\right.$-bromo-2"-chloroethenyl)-bis-(5-methyluracil) (V) & 515.00 \\
\hline 4. & $\begin{array}{l}\mathrm{N}^{(1)} \text {-(1-trifluoromethyl-2,2-dicarbethoxyethenyl)-2,4-dioxo-3,4-dihydro-2H- } \\
\text { pyrimidine (VII) }\end{array}$ & 568.00 \\
\hline 5. & $\begin{array}{l}\text { molecular complex of Bacillus polymyxa } 102 \mathrm{KGU} \text { and 5-methyluracil bis- } \\
\text { derivative }(\mathrm{V})\end{array}$ & 335.00 \\
\hline 6. & 5-FU (control)* & 375.00 \\
\hline & uthor & \\
\hline
\end{tabular}

It has been established that molecular complex of Bacillus polymyxa $102 \mathrm{KGU}$ and 5-methyluracil bisderivative $V$ shows an anti-tumor activity. After treatment by molecular complex of Bacillus polymyxa $102 \mathrm{KGU}$ and 5-methyluracil bis-derivative $V$, the weight of cancer Lymphosarcoma Plissa reduced from $13.9 \pm 1.93 \mathrm{mg}$ to $5.17 \pm 0.09 \mathrm{mg}$, which is $62.8 \%$ growth braking in cancer growth (considerable criteria is $\geq 50.0 \%$ of tumor growth relaxation). Thus, it is 1.26 times greater than standard criteria of cancer treatment by morphological control.

\section{Conclusion}

New mono- and bis-adducts of 5-methyluracil, molecular complex of Bacillus polymyxa $102 \mathrm{KGU}$ and 5-methyluracil bis-derivative were prepared and toxicity-tested for antitumor activity on the cancer Lymphosarcoma Plissa. New convenient methods for the preparation of heterocyclic monoand bis-adducts III-V, VII of 5-methyluracil with 1,1,1-trifluoro-2-bromo-2-chloroethane (halothane) or 1,1-dicarbethoxy-2-trifluoromethyl-2-chloroethylene are also described. The reactions are catalyzed by DB-18-crown-6-complex (at the alkali medium). Investigation of the critical toxicity of compounds, which were synthesized, shows that it has low toxicity: $\mathrm{LD}_{50}$ from $568 \mathrm{mg} / \mathrm{kg}$ up to 335 $\mathrm{mg} / \mathrm{kg}$. Anti-tumor activity of molecular complex of Bacillus polymyxa $102 \mathrm{KGU}$ and 5methyluracil bis-derivative permits us to consider it as physiological active with a perspective investigation as a potential antitumor drug for future treatment in people. The construction of the principle of new medical preparations, on the basis of the saprophytic strains bacterial lectins and heterocyclic bis-adducts, is very possible. 


\section{References}

Adjei, A. A. (1999). Review of pharmacology and clinical activity of new chemotherapy agents for the treatment of colorectal cancer. Clinical Pharmacology, 48, 265-277.

Abou-Gharbia, M., \& Patel-Usha, R. (Eds.). (1988). Polycyclic aryl- and heteroarylpiperazinyl imides as 5-HT ${ }_{1 \mathrm{~A}}$ receptor ligands and potential anxiolytic agents: synthesis and structure-activity relationship studies. Journal of Medical Chemistry, 31(7), 1382-1385.

Alonso, R., Shaw, G., \& Wright, D. (1984). Thermal addition of heterocycles to bicyclic reagents. Journal Chemical Society Perkin Translation, 1(12), 2795-2799.

Anderson, N., \& Lokich, J. (1992). Controversial issues in 5-fluorouracil infusion use. Dose intensity, treatment duration, and cost comparisons. Cancer, 70, 998-1002.

Anttila, M. I., Sotaniemi, E. A., \& Kairaluoma, M. I. (Eds.). (1983). Pharmacokinetics of ftorafur after intravenous and oral administration. Cancer Chemotherapy and Pharmacology, 10, 150-153.

Au, J. L., Wu, A. T., \& Friedman, M. A. (Eds.). (1979). Pharmacokinetics and metabolism of ftorafur in man. Cancer Treatment Report, 63, 343-350.

Baba, H., Kohnoe, S., \& Endo, K. (Eds.). (2000). State of the treatment for gastrointestinal cancer. Gan To Kagaku Ryoho, 27, 1233-1246.

Barlow, R. (1959). Vvedenie v himicheskyy farmacologiy [Introduction to chemical pharmacology].. Moscow, Russia: Foreign literature.

Benz, C., Tills, T., \& Tattelman, E. (Eds.). (1982). Optimal schedule of methotrexate and 5-fluorouracil in human breast cancer. Cancer Research, 42, 2081-2086.

Blohin, N. N., \& Perevodchikova, N.I. (1984). Himioterapia rakovih zabolevaniy [Chemistry therapy of tumor's illnesses]. Moscow, Russia: Medicine.

Brody, G. L., \& Sweet, R. B. (1963). Halothane anesthesia as a possible cause of massive hepatic necrosis. Anesthesiology, 24, 29-37. doi: 10.1097/00000542-196301000-00005

Brown, B. R., \& Sipes, I. G. (1977). Biotransformation and hepatotoxicity of halothane. Biochemical Pharmacology, 26, 2091-2094. doi: 10.1016/0006-2952(77)90256-8

Perevodchikova, N. I. (Ed.) (2005). Chimioterapia rakovih zabolevaniy [Chemotherapy of cancerous diseases] (2nd ed.). Moscow, Russia: Practical medicine.

Kovalenko, E. A. (1990). Vnekletochnie lektini bakteriy [Extracellular bacterial lectins]. Microbiol. Zhurn., 5(3), 92-99.

Longley, D. B., \& Harkin, D. P. (2004). Mechanisms of action of 5-fluorouracil. Nature Revues Cancer, 4, $230-238$.

Noordhuis, P., \& Holwerda, U. (2004). 5-fluorouracil incorporation info RNA and DNA in relation to thymidilate synthetase inhibition human colorectal cancer. Annals of oncology, 15, 1025-1032. doi: 10.1093/annonc/mdh264. PMid:15205195

Prozorovskiy, V. B., Prozorovskiy, V. P., \& Demchenko, V. M. (1978). Ekspress-metod opredeleniya sredney effektivnosty dozy i ego oshibka [Express - method of middle effective dose determination and its mistake]. Pharmacology and toxicology, 41(4), 407-509.

Sophyina, Z. P., Sophyina, A. B., Goldin, A., \& Kmein, A. (Eds.) (1979). Eksperimentalnaya otsenka protivoopuholevyh preparatov $v$ SSSR i SShA [The experimental value of the antitumour drugs in USSR and USA]. Moscow, Russia: Medicine.

Welchinskaya, H., Kuzmenko, I., \& Ilchenko, A. (1997). Geterotsikliceskie soedineniya s farmakofornimy galogenzameshenimy grupamy [Heterocyclic compounds with pharmacophore halogensubstituted groups]. Journal of Heterocyclic Chemistry, 7, 967-971.

Yagupolskiy, L. M. (1988). Aromaticheskie I geterocyklicheskie soedineniya s ftorsoderjashimy zamestitelyamy [Aromatic and heterocyclic compounds with fluoro-containing substitutes]. Kiev, Ukraine: Naukova dumka. 